\title{
Advanced Trajectory Planning for Production Energy Estimation
}

\author{
Ralf Stetter*, Andreas Paczynski*, Piotr Witczak, Benjamin Staiger** \\ ${ }^{*}$ Hochschule Ravensburg-Weingarten \\ **Kirchner Konstruktionen $\mathrm{GmbH}$
}

\begin{abstract}
This paper is based on a current research project and describes advanced trajectory planning methods which aim to contribute to the estimation of the energy consumption in the production of goods. The energy a product requires during its operation is the object of many activities in research and development nowadays. However, the energy necessary for the production of goods is very often not analyzed in so much detail. The energy consumption in a product production and disposal is determined very early in its development process by designers and engineers, for example by selection of raw materials, explicit and implicit requirements concerning the manufacturing and assembly processes or by decisions concerning the product architecture. Today, developers and engineers dispose of manifold design and simulation tools which can help to predict the energy consumption during a product operation relatively accurately. In contrast, tools with the objective to predict the energy consumption in production and disposal are unavailable, apart from the first material databases such as Eco Materials Adviser in Autodesk. Transportation processes are the important aspects of production. Product components and unfinished products have to be transported from the receipt of goods to stock and then to the manufacturing or assembling station during all phases of the manufacturing and assembling processes. The energy consumption estimation of these logistic process is only possible if probable and sensible routes of movements are used as a basis. This paper aims to present an approach to apply trajectory planning methods in order to develop such routes and consequently to be able to estimate the energy consumption.
\end{abstract}

Keywords: fuzzy logic, energy consumption prediction, production

DOI: 10.14313/PAR_204/70

$\mathbf{T}$ he energy necessary for the production of goods, e.g. the energy for raw material generation, for casting or for milling can very often not be analyzed in depth in early stages of product development processes, because today the common tools of product development, such as geometry generating tools as CAD (computer aided design), do not dispose of any possibility to support desi- gners and engineers in this endeavor. The importance of the energy for production becomes apparent for instance in the field of passenger cars. In this field even conservative studies (4) get to the conclusion that about $20 \%$ of the total energy caused by a product is needed for the production and about $10 \%$ for the disposal. The energy consumption in production and disposal is determined very early in the product development process by designers and engineers, for example by selection of raw materials, explicit and implicit requirements concerning the manufacturing and assembly processes or by decisions concerning the product architecture.

\section{Introduction}

Today, developers and engineers dispose of manifold design and simulation tools which can help to predict the energy consumption during operation relatively accurately. For instance, the energy consumption of a car under development expressed in liter per $100 \mathrm{~km}$ can be predicted with an accuracy of 0.1 liters years before this specific car will be built. Frequently, large expenditures are invested only to achieve relatively small improvements of the energy consumption in operation. In the area of the motor vehicles for example measures such as the start-stop-systems or hybrid systems are applied which can achieve improvements of the energy efficiency in the one-digit percent area.

In contrast, tools with the objective to predict the energy consumption in production and disposal are not available, apart from the first material databases such as Eco Materials Adviser in Autodesk. Moreover, initial investigations in the research project showed that the available databases deviate for identical materials and weights up to orders of magnitude from one another. Very probably, a conscious view of the energy consumption in the production can lead to clear energy savings. This statement cannot be quantified in the moment for this area; however an analogy concerning systems for costs prognosis can underline the potential. In this area the conscious consideration of costs during design led in the past to cost savings up to $70 \%$ without restricting the functionality of the components and products (see for example (7)). Energy saving potential in the production in a similar 
order of magnitude could lead to improvements in the two-digit percent area of the entire energy balance of a product; improvements of this dimension can hardly today be reached in the energy consumption in the operation. Today designers and developers must more or less "blindly" decide because it is in today's industrial reality impossible to predict the energy consumption in the production. It is hypothesized that intelligent tools and procedures can shift the knowledge concerning production energy consumption into earlier phases and massively can increase the improvement potential (fig. 1).

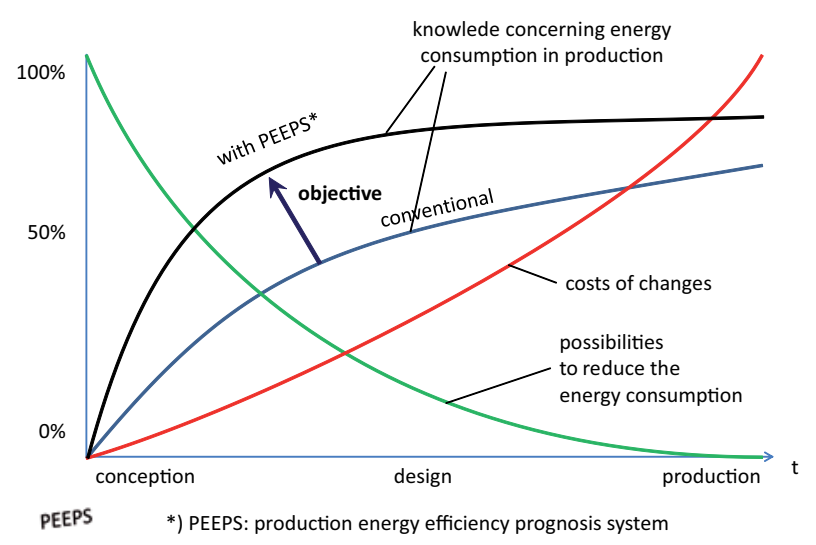

Fig. 1. Early evaluation of production energy consumption

Rys. 1. Wczesna ocena zapotrzebowania procesu produkcyjnego na energię

In this representation, which is based on similar representations in the area of early determination of product properties (compare Stetter\&Bernard (1)), it is clearly recognizable that in the early phases of the product development the energy consumption can be influenced in a far more reaching manner by product changes and this in connection with considerably smaller change costs.

The energy consumption in productions has several origins (fig. 2).

The primary shaping, the forming, joining and surface treatment are addressed in other sub-projects of this research endeavor. This paper is focusing on transport and logistics. This investigation is aiming at an early estimation of the energy needed for transporting product components and unfinished as well as finished product throughout the company's buildings. The vision behind this work is an information system which will automatically generate probable transportation trajectories on the basis of probable production layouts and will therefore be able to estimate the energy necessary for these transportation processes. The product designers can then very early generate multiple variants of the product and especially its architecture. The designer can then compare the energy consumption of the different variants and can choose the most energy efficient - the most sustainable - solution in a very early phase of product development.

\section{State of the art}

To the state of the research belong the numerous research activities in the area of eco design. Tischner et al. (16) offer a good overview. In these activities, the energy consumption plays usually a central role and in the frame of the Life Cycle Assessment (LCA) also the production is considered as a part of the life cycle. In this scientific area especially the international standard ISO 14031 is to be mentioned, which supports a comprehensive judgment of the sustainability. Notable are the works of Herrmann et al. (8) which connect the methodologies of the life cycle assessment, multi criterion analysis and environment achievement indicators. In the last years, frequently the also so-called "exergie" as a central measurement means for sustainability moved into the center of interest (5). Current works also show first integrations of sustainability considerations and tools also into CAD systems, however solely an integration is achieved by means of integrating check lists. A current project at the TU Chemnitz aims on the IT support of energy sensitive product development, however here the main focus is on the aspects product data management (PDM) and Enterprise Resource Planning (ERP) (13). Prior works, which also need to be considered, concern the integration of information about the energy consumption in the first production steps of the raw materials. The CAD systems Autodesk Inventor and Solidworks expansions offer which should permit to estimate the resource consumption already in the design phase. The current version of Autodesk Inventor 2012 offers the expansion Eco Material Adviser, which by means of an Internet based database can amongst others provide information concerning the materials, the raw material fabrication procedure, the energy consumption, the $\mathrm{CO}_{2}$ emission and the water consumption. The database is operated in collaboration with Granta design and includes information to 3,000 materials and selected fabrication procedures. Next to Inventor 2012, also the current version of offers Solidworks an expansion "Sustainability" which provides information concerning the $\mathrm{CO}_{2}$ emission and the energy consumption, to the air load and to the water load. The expansion "Sustainability" offers in addition the possibility to find automatically materials, which combine more favorable environmental characteristics with similar mechanical and/or physical characteristics. Both systems do only consider the final weight of the part, decisive aspects of the product geometry and product origin are not analyzed in these systems.

This paper is focusing on advanced trajectory planning methods which aim to contribute to the estimation of the energy consumption in the production of goods. The state of the art of trajectory planning needs to include both theoretical analyses of the problem and the development of algorithms for finding effective solutions for planning globally optimal paths. Research in trajectory planning dates back to the pioneering work done by Dubins (6). Dubins considered the problem of a particle moving in a plane with a constant velocity, and with a constraint 


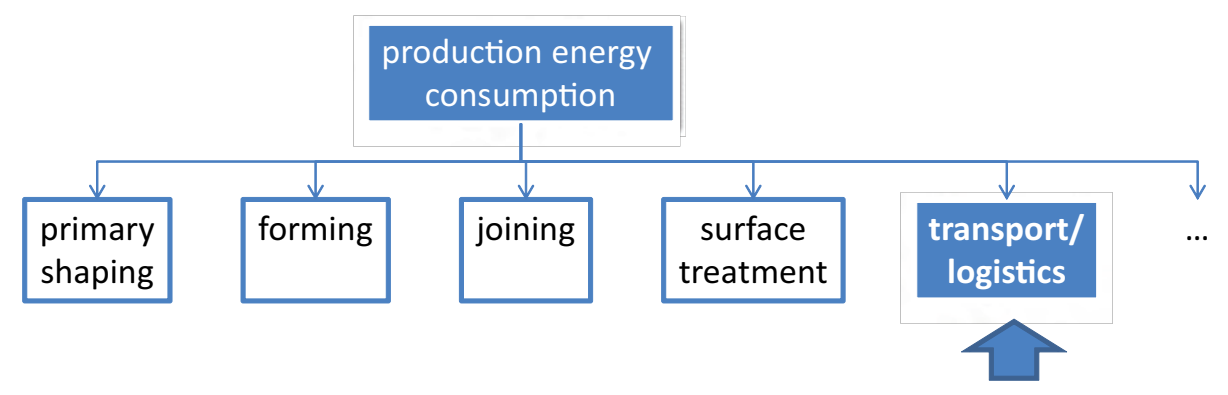

Fig. 2. Origins of production energy consumption

Rys. 2. Obszary zużycia energii w procesie produkcyjnym

on its minimum radius of curvature. He proved that the optimal trajectories are made up of arcs of circles with minimum radius of curvature and segments of straight lines. Reeds and Shepp (12) took this work a step further and derived another set of finite shortest path configurations for vehicles that move both forward and backward. Using this finite family of curves, it is rather simple to design an algorithm to find the shortest path between any two configurations. But, the presence of obstacles and the fact that a mobile vehicle needs a continuous path to be able to follow it accurately made such a solution impractical. Finding shortest paths with continuous curvature came to be known as the generalized offline path planning problem for car-like robots. It is a difficult task even with the absence of obstacles and remained an open problem for a number of years until it was proved to be NP-Hard by Reif and Wang (14).

A few attempts that used probabilistic methods and randomized algorithms were used to develop algorithms for the generalized path planning problem. Probabilistic path planners (PPP) are guaranteed to solve a problem for which a solution exists within infinite time. That is, as the running time of the algorithm goes to infinity, the probability of solving it converges to one. In some cases, a guaranteed probability value of reaching the optimal solution is given for reasonable (polynomial) running times. Just as in the case of PPP, randomized path planners (RPP) can also be proven to have a guaranteed probability of reaching an optimal solution in polynomial time. The differences in the two methods arise from the technique used to solve the problem. PPP algorithms use iterative procedures that perform neighborhood walks to find an optimal solution, while RPP algorithms use random walks through the solution space to find an optimal solution (10).

PPP algorithms are typically broken down into two or more stages. The first stage checks if the problem is solvable (a decision problem). If the problem is found to be solvable, the second stage finds an approximate solution, which is then optimized by the third stage that uses an iterative search method. A good example of a PPP is given by Laumond et al. (9).

RPP algorithms are somewhat similar to PPP in the sense that this method also involves two or more search stages. RPPs typically use randomized heuristics such as simulated annealing and genetic algorithms. Bessiere et al. (2) have developed one such technique that has two stages (search and explore). The search stage finds if it is possible to "simply" reach the goal. The explore stage collects information about the environment and optimizes the path found in the search stage by using landmarks placed all over the environment. Exploration of the environment is done with the help of a genetic algorithm.

Many deterministic approaches make certain assumptions to help simplify the problem down to a more tractable one. This has allowed the use of simple and efficient heuristic type solutions to tackle practical problems at considerably low running times. The most popular of these assumptions is to assume that an admissible trajectory can be obtained from a discontinuous collision free path made up of straight-line segments and circular arcs of bounded curvature. A well tried and tested method that was first introduced by Perez and Wesley (11) is the visibility graph search method. This method reduces the obstacle map along with the start and goal points down to a graph structure where the visibility of each node (vertices of obstacles) with respect to other nodes in the graph is computed. The shortest path is built by connecting visible nodes beginning from the start node and ending with the goal node (10).

There has also been a substantial amount of work in the areas of multi-robot path planning, path planning among moving obstacles and trailer path planning.

The presented state of the art presents a solid basis; however, in literature no attempts for trajectory generation with the objective of energy estimation in early stages of product development are present.

\section{Framework}

This section starts with a short description of the situation of an engineer who is planning the geometry of components and the architecture of a new product. The energy consumption during the production of the product is amongst others dependent on the transportation processes. In order to estimate the energy for these transportation processes the first main information are the distances to be covered between the different stations where manufacturing, assembling or surface treatment processes 


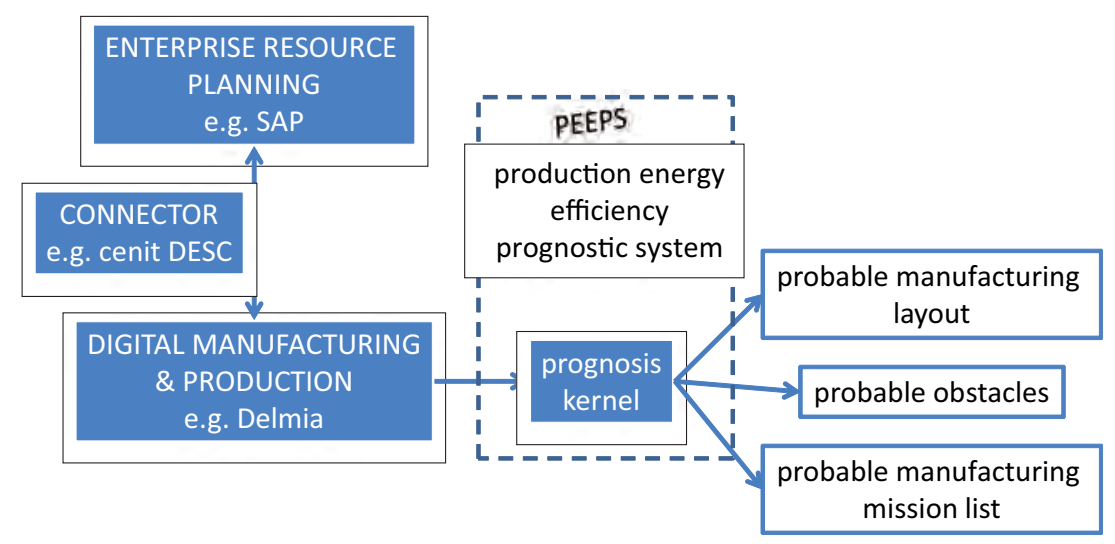

Fig. 3. Prognosis kernel

Rys. 3. Jądro system prognostycznego

are performed. Consequently, the engineer would need to plan the whole manufacturing, assembling and surface treatment process. For products which are not completely new (which is the case for more than $90 \%$ of all products) these processes are captured in the enterprise resource planning (ERP) systems such as SAP and can be used for the sake of the estimation. The next step would be a mapping of the stations during the process to physical locations in order to be able to measure the distances between the stations. Again, for products which are not completely new these locations are available in the layout planning tools which are usually part of the digital manufacturing and production systems such as DELMIA. Today these tools are connected in the IT infrastructure of many companies by certain connectors such as DESC. A component of a production energy efficiency prognosis system could get this kind of information from the interfaces of a digital manufacturing and production system and could transfer them into a form useable by other components of this system (fig. 3).

As state above, one important entity of information is the list of manufacturing, assembling and surface treatment processes which can be referred to as mission list. Essentially a mission list (ML) is a vector with as many elements as necessary operations:

$$
\mathrm{ML}=\left[\mathrm{PSP}_{\mathrm{i}}\right]_{\mathrm{i}=0}^{\mathrm{i}=\mathrm{n}} ; \text { for } \mathrm{i}=1, \ldots, \mathrm{n}
$$

with $\mathrm{PSP}_{\mathrm{i}}$ production steps with a respective specific ID and $n$ the necessary number of such production steps.

The next entity is the assignment of production steps to production stations. This assignment can be done in a $2 \times n$ assignment matrix $(\mathrm{AM})$ :

$$
\mathrm{AM}=\left[\mathrm{PSP}_{\mathrm{i}} \mathrm{PST}_{\mathrm{i}}\right]_{\mathrm{i}=0}^{\mathrm{i}=\mathrm{n}} ; \text { for } \mathrm{i}=1, \ldots, \mathrm{n}
$$

with PSP $_{i}$ production steps with a respective specific ID and $\mathrm{PST}_{\mathrm{i}}$ production stations with a respective specific ID.

As stated above, a further important entity of information is the arrangement of the production station captured in a production layout. Here only a probable layout can be hypothesized up front during prognosis. A proba- ble production layout matrix (PPLM) is a $n \times m$ matrix using an appropriate grid.

$$
\operatorname{PPLM}=\operatorname{PPST}_{\mathrm{ij}}{ }_{\mathrm{i}, \mathrm{j}=0}^{\mathrm{i}, \mathrm{j}=\mathrm{n}, \mathrm{m}} \text {; for } \mathrm{i}=1, \ldots, \mathrm{n} \text { and } \mathrm{j}=1, \ldots, \mathrm{m}
$$

with $\operatorname{PPST}_{\mathrm{ij}}$ diagonal elements which describe probable production stations with their respective ID.

For the trajectory generation also information about obstacles in the production environment are necessary. These can also be generated from information in the digital manufacturing and production system and formulated in an obstacle matrix. An obstacle matrix (OM) is a $n \times m$ matrix using an appropriate grid.

$$
\mathrm{OM}=\mathrm{OP}_{\mathrm{ij}}^{\mathrm{i}, \mathrm{i}, \mathrm{j}=0 \mathrm{n}, \mathrm{m}} ; \text { for } \mathrm{i}=1, \ldots, \mathrm{n} \text { and } \mathrm{j}=1, \ldots, \mathrm{m}
$$

with $\mathrm{OP}_{\mathrm{ij}}$ diagonal elements which describe probable obstacles. Here a value of "0" denotes "no obstacle" at this position of the grid and " 1 " denotes "obstacle present" at this position of the grid. Additionally regions of danger respectively security around obstacles can be indicated in this matrix. The inner security zone is denoted with a value of " 0.5 " in the matrix and is characterized by a rather high risk to damage the obstacle or the vehicles if unwanted influences such as slippery floors occur. In the outer security zone damages are unlikely even if such conditions would be present. This zone is denoted with a value of " 0.25 " in the obstacle matrix. In this stage of the process no dynamic obstacles are considered as they are also not captured in the digital manufacturing and production system.

With the listed information a second section of a production energy efficiency prognosis system could generate probable trajectories and a third section of this system could than estimate the energy consumption for instance based on the traveled distance, probable velocities and probable rolling friction, probable air drag, probable inclination and probable acceleration (fig. 4).

The result of these steps is an estimation of the probable energy consumption in production - in the final vision of the project all intermediate steps are carried out automatically be the production energy efficiency progno- 


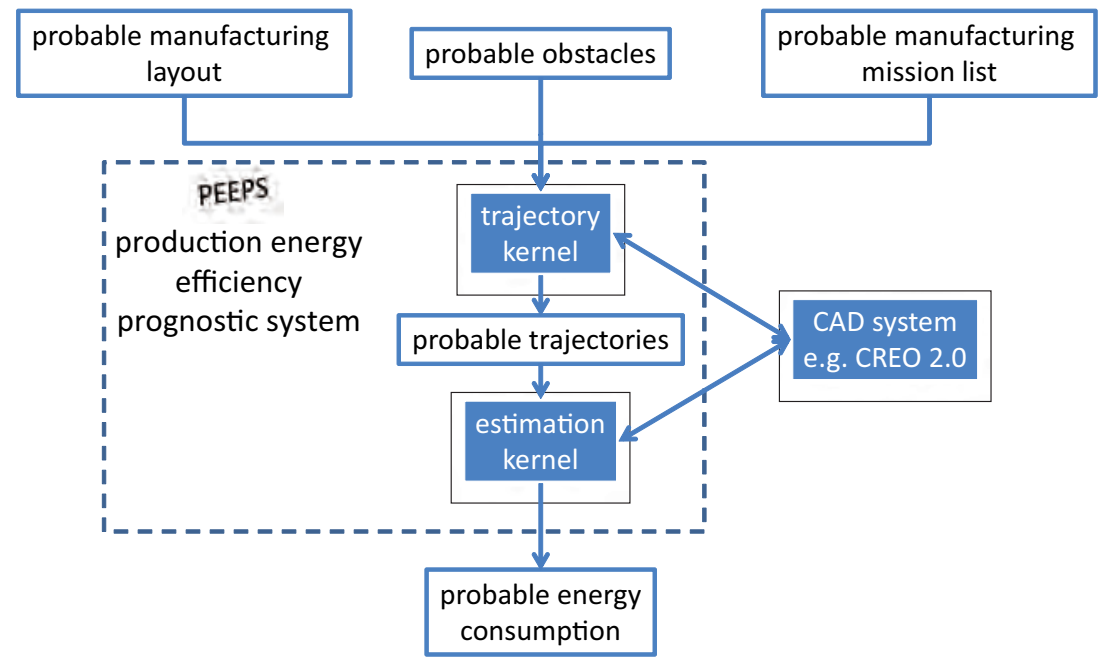

Fig. 4. Trajectory kernel and estimation kernel

Rys. 4. Jądro trajektorii i jądro oceny

sis system and thus allowing the engineer to test several product component and product architecture alternatives. On this basis he may consciously decide for the most sustainable alternative with the smallest energy consumption possible; this decision possibility is currently not available to engineer in industrial practice.

One important element of the whole system is the trajectory kernel. Two alternatives for the automatic generation of sensible trajectories are described in the next two sections - a basic trajectory kernel based on refined ideas of dubins vehicles and an enhanced trajectory kernel.

\section{Basic Trajectory Kernel}

A trajectory kernel is a function block (a software component) which can be used for the realization of several functionalities (15). It allows calculating the minimum time to realize a certain transportation task but also minimum distances which are usually desirable from the viewpoint of energy efficiency. Consequently, in this project and in prior work (15) a concept of a very basic trajectory kernel which still delivers relatively good trajectories was developed. For autonomous vehicles trajectories need to be generated in a two-dimensional plane. A trajectory can be described as a parametric curve (3):

$$
\vec{p}=\vec{p}(u)
$$

The trajectory is completely defined only when the motion law is provided:

$$
u=u(t)
$$

Here the function $u(t)$ is a function which derivatives are velocity, acceleration and jerk. This trajectory kernel generates such parametric curve and the respective function and is based on the use of the simple geometric shapes circle and tangential line (motion primitives - fig. 5).

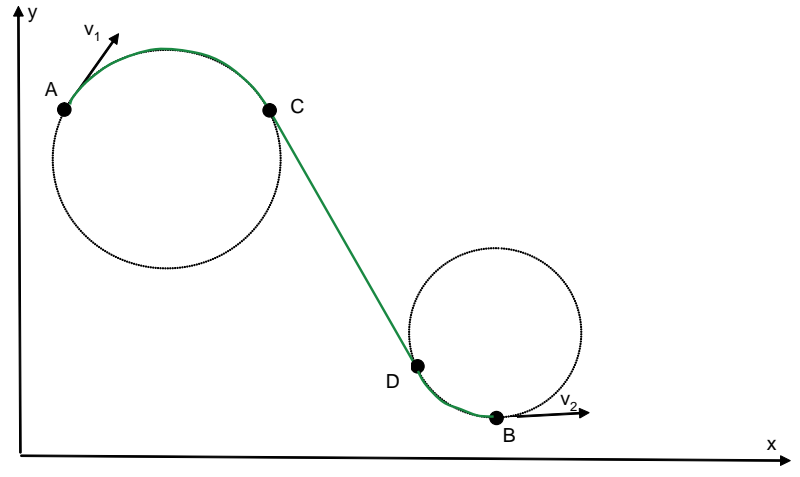

Fig. 5. Basic trajectory kernel - motion primitives

Rys. 5. Podstawowe jądro trajektorii - prymitywy ruchu

Such simple geometric shapes - also called motion primitives - were applied multiple times in research and industry (compare e.g. the so-called Dubins vehicles (6). For the basic trajectory kernel additionally some sensible simplifications are made:

- The vehicle starts form an operation at stand-still and is then accelerated with constant acceleration to a predetermined optimal velocity (usually in the range of $80 \%$ of the maximum velocity).

- The radius of the basic shape "circle" is always determined by the velocity of the vehicle. The friction contact of a wheel to the floor only allows the transfer of a certain amount of centrifugal forces. In this kernel a given friction parameter is used in order to determine an appropriate circle radius for a certain speed (fig. 6).

- Acceleration and deceleration are only realized on the straight tangential lines. In this way the smallest circles possible can be used, as the friction contact in curves is not additionally loaded by inertia forces resulting from acceleration and deceleration.

- For the acceleration and deceleration on the straight line a trapezoidal trajectory was applied (compare Biagiotti\&Melchiorri (3)). This profile is a very common method to obtain trajectories with a continuous velo- 


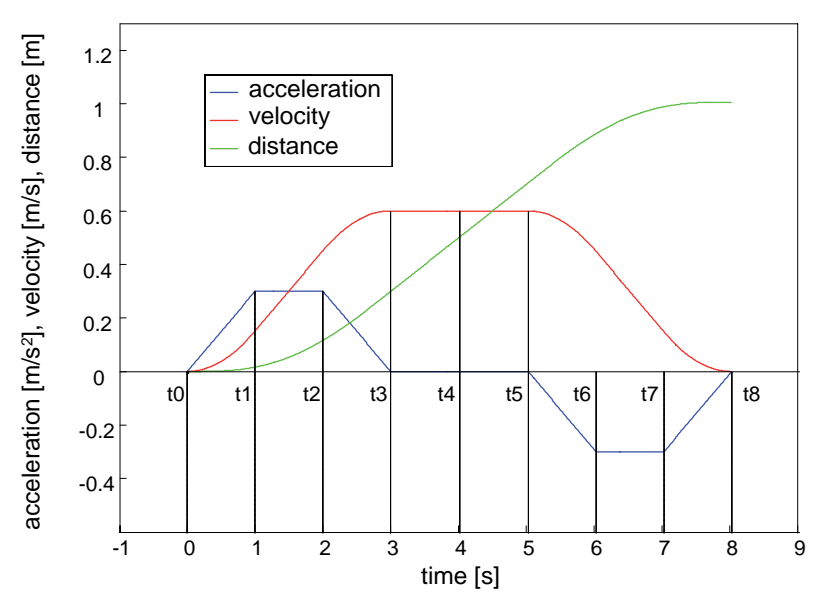

Fig. 6. Basic trajectory kernel - acceleration and deceleration Rys. 6. Podstawowe jądro trajektorii - przyspieszanie i zwalnianie

city profile and is the simplest possibility which can be practically realized (fig. 6). Jumps in the acceleration occur and lead to interruptions on the vehicle and its load. This problem will be addressed in the next section - enhanced trajectory kernel.

The trajectory kernel also has to take obstacles from the obstacle matrix into consideration. Here also the motion primitive circle is used in order to design a sensible detour trajectory (fig. 7).

The detour trajectory is based on circle segments and the radius of this circle segments is again depending on the velocity of the vehicle. Deceleration and acceleration are not realized during this part of the motion in order to prevent additional load on the friction contact. Around the obstacles an inner security zone (indicated by 0.5 in the obstacle matrix and an outer security zone (indicated by 0.25 in the obstacle matrix) is visible. The detour trajectory may touch the outer security zone; more dangerous trajectories would be possible but are not considered in this early phase of trajectory planning.

For the operation of the basic trajectory kernel the initial position and velocity vector and the desired position and velocity vector needs to be given. Usually the

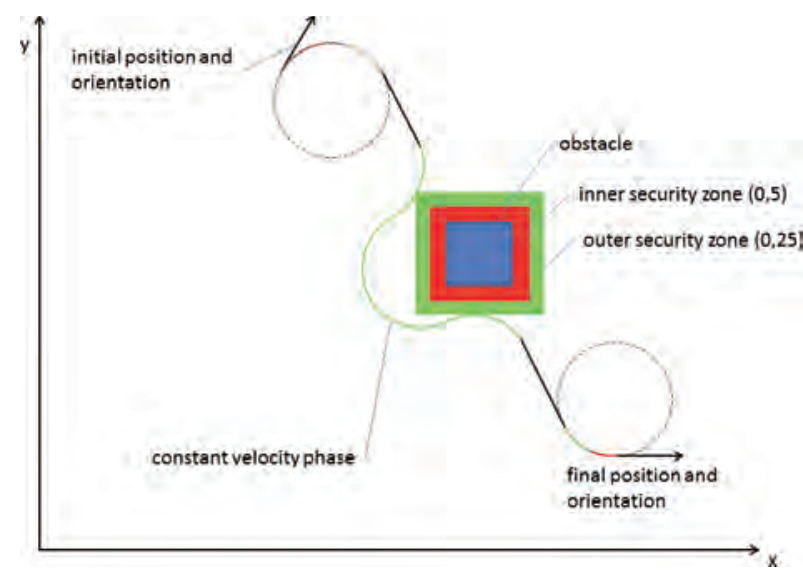

Fig. 7. Basic trajectory kernel - obstacles

Rys. 7. Podstawowe jądro trajektorii - przeszkody initial point will be the current position and the desired position will be the location where some kind of an activity has to be executed. Additionally values such as maximum total acceleration and maximum speed need to be given. The application of the trajectory kernel can deliver the following results:

- a table of position and velocity vectors with a line showing a given time interval (e.g. $50 \mathrm{~ms}$ ),

- the position of the motion primitives circle and line,

- the minimum time needed to perform the mission under the given conditions (maximum velocity and maximum acceleration) and

- the prerequisites for determining the energy consumption.

Figure 8 summarizes the main considerations of the simplified trajectory kernel.

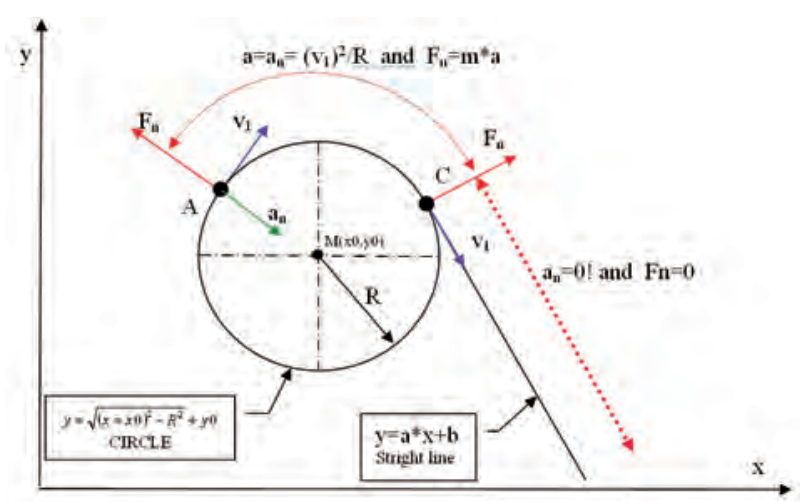

Fig. 8. Basic trajectory kernel - main considerations

Rys. 8. Podstawowe jądro trajektorii - podstawy analizy

The trajectory kernel can then also be used to create alternative trajectories using different leading criteria e. g. time or energy consumption.

Today a large number of algorithms for trajectory synthesis are available - a good overview is given by Biagiotti\&Melchiorri (3). The distinctive quality of the presented basic trajectory kernel in comparison to the numerous other trajectory generation algorithms are the straight-forward strategy for avoiding unnecessary acceleration and deceleration (acceleration and deceleration only on the tangential lines), the possibility to set different priorities i.e. optimization criteria (time/energy/production space) and the use of basic shape combination. These characteristics and strategies which consider the physical properties of autonomous vehicles largely reduce degrees of freedom and allow fast calculations but still deliver a sensible trajectory. Due to the analytical nature of the approach a safe behavior of the vehicle can be guaranteed.

\section{Enhanced Trajectory Kernel}

As stated above, the main problem of the basic trajectory kernel can be the interruptions of the vehicle and its load due to the jumps in the acceleration profile (infinite jerk). In the case of vehicles it is sensible to consider the two components path acceleration (resulting from accelera- 
tion and deceleration) and normal acceleration (resulting from the curvature of the path). The effect to the vehicle and its load is the same; it is therefore desirable to have smooth changes of the resulting acceleration vector (continuous total acceleration strategy). Figure 9 shows the approach for the enhanced trajectory kernel.

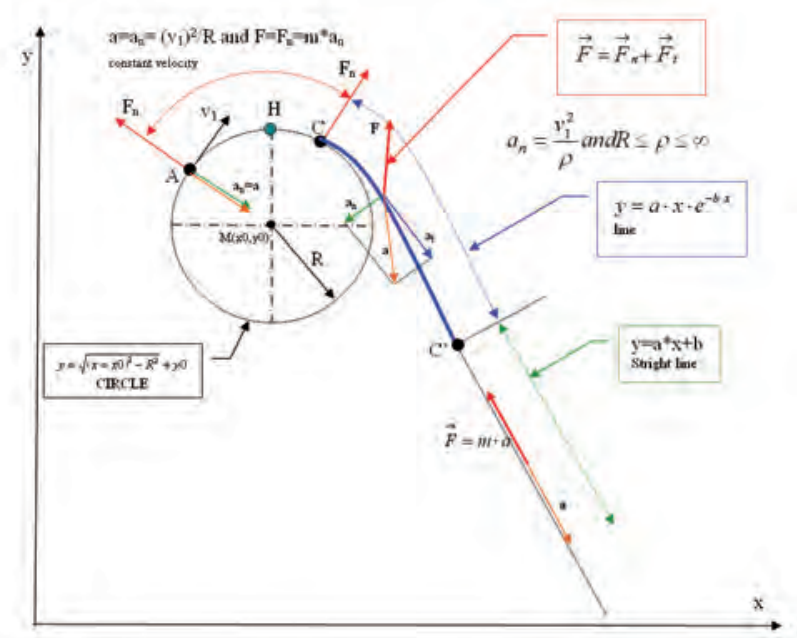

Fig. 9. Enhanced trajectory kernel

Rys. 9. Zaawansowane jądro trajektorii

Two main points characterize the considerations: firstly it is now necessary also to consider the acceleration or deceleration in the initial and desired position - i.e. to know the rotation of the velocity vector at the beginning and the end. Secondly at all instances of the trajectory where a change from a circle to a line of vice versa is necessary a smoothing sections has to be integrated. Elaborate investigations have show that an e-function is an appropriate solution to realize such smoothing sections (fig. 9). Another possible approach would be, for instance, the clotoid function, which was applied for rail tracks for the sake of smoothing between curves and straights. The clotoid function is the curve defined by parametric equations:

$$
\begin{aligned}
& x(t)=a \sqrt{\pi} \int_{0}^{t} \cos \frac{s^{2} \pi}{2} d s \\
& y(t)=a \sqrt{\pi} \int_{0}^{t} \sin \frac{s^{2} \pi}{2} d s
\end{aligned}
$$

However, these functions are very complicated and require solving an integral and were therefore not chosen for a quick trajectory kernel.

To conclude, the continuous total acceleration strategy of the enhanced trajectory kernel applied in order to achieve fewer interruptions on the vehicle and on transported goods. The changes of the trajectory are minor and can be applied for instance only during operation but can be ignored for rough mission planning, for collisions forecast and preliminary avoidance and other activities in the preparation a single or multiple missions of autonomous vehicles.

\section{Summary}

The earlier a product development engineer can estimate the energy the product he/she is developing will cause in production the better this engineer can make conscious decisions concerning product architecture and product geometry which can lead to reduced energy consumption in production. A large scale project at the University Ravensburg-Weingarten is aiming to support engineers in this estimation. One important aspect is the energy needed for transporting goods (products and their components as well as tools and other items) in the manufacturing and assembling factories. The research described in this paper aims to develop probable and sensible routes of movements as a basis for an energy consumption estimation of these logistic processes. In order to do so a framework was developed and the application of an exemplary trajectory kernel was explained. Further steps will include other algorithms for trajectory development and comparisons with realistic data from producing companies. The results of these research steps will result in one building block for a production energy estimation system (PEEPS).

\section{Aknowledgements}

This project is supported by a grant from the European Regional Development Fond and the Ministry of Science, Research and the Arts of Baden-Württemberg, Germany (further information can be found under: www.rwb-efre. baden-wuerttemberg.de).

\section{Bibliography}

1. Bernard R., Stetter R., Early Determination of Product Properties, [in:] HUBKA, V. (Hrsg.); et al. Proceedings of ICED 97, Tampere. Zürich: Edition Heurista, 1997, S. 2/675-2/680.

2. Bessiere P., Ahuactzin J.M., Talbi E.G., Mazer E., The ariadne's clew algorithm: Global planning with local methods, IEEE Intelligent Robots and Systems Conference, 1993.

3. Biagiotti L., Melchiorri C., Trajectory Planning for Automatic Machines and Robots, Spinger, Berlin 2008.

4. Brake M., Die Ökobilanz der Abwrackprämie ist negativ. Telepolis Wochenschau, 10.03.2009, 2009.

5. Coatana E., Kuuva M., Nordlund H., Makkonen P.E., Saarelainen T., An uniform environmental metric based on exergy for early design evaluation, „International Journal of Environmentally Conscious Design and Manufacturing", Vol. 13, No. 2, 2007.

6. Dubins L.E., On curves of minimal length with a constraint on average curvature, and the prescribed initial and terminal positions and tangents, „American Journal of Mathematics", 79(3): 497-516, 1957.

7. Ehrlenspiel K., Kiewert A., Lindemann U., Kostengünstig Entwickeln und Konstruieren. Springer, 2007.

8. Hermann B.G., Kroeze C., Jawjit W., Assessing environmental performance by combining life cycle as- 
sessment, multi-criteria analysis and environmental performance indicators, „Journal of Cleaner Production", Vol. 15, 1787-1796, 2007.

9. Laumond J.P., Jacobs P.E., Michel T., Murray R.M., A motion planner for non-holonomic mobile robots, "IEEE Transactions on Robotics and Automation", 1994.

10. Pasha A., Path planning for nonholonomic vehicles and its application to radiation environments, Report, University of Florida, 2003.

11. Perez T.L., Wesley M.A., An algorithm for planning collision free-paths among polyhedral obstacles, Communications of the ACM, 1979.

12. Reeds J.A., Shepp R.A., Optimal paths for a car that goes both forward and backward, „Pacific Journal of Mathematics", 1991, 145(2): 367-393.

13. Reichel T., Rünger G., Steger D., Xu H., IT-Untersüttzung zur energiesensitiven Produktentwicklung, Chemnitzer Informatik-Berichte, 2010.

14. Reif J., Wang H., The complexity of the two dimensional curvature constrained shortest path problem. Robotics: The Algorithmic Perspective: The Third Workshop on the Algorithmic foundations of Robotics, Natick (MA), 1998.

15. Seybold L., Pieczynski A., Paczynski A., Krokowicz J., Stetter R., Development of a trajectory kernel for autonomous vehicles, Proceedings of the 9th Workshop on Advanced Control and Diagnosis, 2011.

16. Tischner U., Schmincke E., Rubik F., Was ist EcoDesign, Ein Handbuch für ökologische und ökonomische Gestaltung. form Praxis, 2000.

\section{Zaawansowane metody planowania trajektorii w estymacji zużycia energii w procesach produkcyjnych}

Streszczenie: W artykule omówiono wyniki obecnie realizowanego projektu badawczego i przedstawiono zaawansowane metody planowania trajektorii, które mają przyczynić się do szacowania zużycia energii podczas produkcji towarów. llość energii, jaka jest wymagana do wytworzenia produktu jest obecnie przedmiotem wielu rozważań i prac badawczo-rozwojowych. Jednakże, bardzo często nie można porównać dogłębności analiz energii koniecznej do produkcji wyrobów. Zużycie energii w produkcji i sprzedaży ustalane jest bardzo wcześnie w procesie rozwoju produktu przez projektantów i inżynierów, np. przez dobór surowców, jawnych i ukrytych wymagań dotyczących procesów produkcyjnych i montażowych, lub przez decyzje dotyczące konfiguracji produktowej. Aktualnie deweloperzy i inżynierowie dysponują różnorodnymi narzędziami projektowymi i symulacyjnymi, które mogą pomóc stosunkowo dokładnie przewidzieć zużycie energii podczas pracy. Narzędzia, których celem jest przewidywanie zużycia energii w produkcji i sprzedaży nie są dostępne, z wyjątkiem pierwszych baz materiałowych, takich jak Eco Materials Adviser (firmy Autodesk). Procesy transportu są ważnym aspektem produkcji. We wszystkich fazach procesów produkcji oraz montażu, komponenty pro- duktu oraz niedokończone produkty muszą być transportowane od odbioru towarów do magazynu, i następnie do miejsca produkcji lub składowania. Oszacowanie zużycia energii w procesach logistycznych jest możliwe tylko wtedy, gdy jako podstawę można wziąć prawdopodobne i sensowne trasy ruchu. Niniejszy artykuł ma na celu przedstawienie nowego sposobu planowania trajektorii w celu wskazania optymalnych tras, a w konsekwencji oszacowania zużycia energii.

Słowa kluczowe: logika rozmyta, predykcja zużycia energii, produkcja

Artykuł recenzowany, nadesłany 24.06.2013 r., przyjęty do druku 10.01.2014 r.

\section{Prof. Ralf Stetter, PhD Eng}

$\mathrm{He}$ is professor for design and development in automotive technology, vice dean of the department of mechanical engineering and head of the Computer Aided Design Laboratory at the Hochschule Ravensburg-Weingarten, Germany and project manager at the steinbeis transfer center "automotive systems".

e-mail: stetter@hs-weingarten.de

\section{Prof. Andreas Paczynski, PhD Eng}

$\mathrm{He}$ is professor for Mechatronics Engineering at the department of Technology and Management at the Hochschule Ravensburg-Weingarten in Weingarten, Germany. He is engaged in area of the high dynamic mechatronic drives. e-mail:paczynski@hs-weingarten.de

\section{Piotr Witczak, MSc}

Received B.Sc and M.Sc degrees from the University of Zielona Gora, Zielona Gora, Poland in 2010 and 2012 respectively. Currently he pursues Ph.D on the University of Zielona Gora. He is currently working as a Research Fellow on University of Applied Sciences Ravensburg-Weingarten, Weingarten, Germany. His research interests include fault tolerant control, efficient model

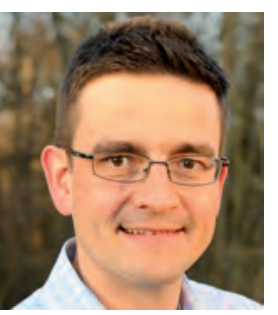
predictive control, LPV systems and performance in unmanned ground and air vehicles.

e-mail: P.Witczak@weit.uz.zgora.pl

\section{Benjamin Staiger}

Dipl. Wirtschaftsinformatiker $(\mathrm{FH})$ is responsible for innovation, IT and administration at Kirchner Konstruktionen $\mathrm{GmbH}$ in automotive technology. $\mathrm{He}$ is CEO of UReality, a company for mobile software solutions with focus on augmented reality.

e-mail: bstaiger@kirchner-kon.de
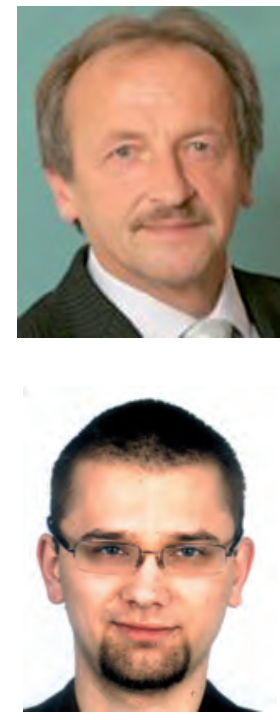

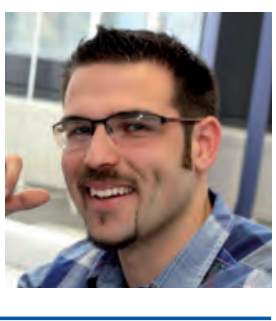

